\title{
RESEARCH PAPER \\ Spray deposition on weeds of common bean crops
}

\author{
Andreia C. P. Rodrigues-Costa ${ }^{1}$, Dagoberto Martins ${ }^{2}$, Neumárcio V. Costa ${ }^{1}$, and \\ Maria R. R. Pereira ${ }^{2}$ \\ ${ }^{1}$ Centro de Ciências Agrárias, Universidade Estadual do Oeste do Paraná (UNIOESTE), 85960-000, Caixa \\ Postal 91, Marechal Cândido Rondon, Brasil. \\ ${ }^{2}$ Faculdade de Ciências Agronômicas, Universidade Estadual Paulista (UNESP), 18610-307, Caixa Postal \\ 237, Botucatu, Brasil.
}

\begin{abstract}
A.C.P. Rodrigues-Costa, D. Martins, N.V. Costa, and M.R.R. Pereira. 2011. Spray deposition on weeds of common bean crops. Cien. Inv. Agr. 38(3): 357-365. Weed control failure in common bean (Phaseolus vulgaris L.) production may be related to inappropriate herbicide application techniques. The purpose of this study, therefore, was to evaluate the amount of spray solution deposition that occurred on the weeds, Bidens pilosa L. and Brachiaria plantaginea (Link) Hitch., both within and between rows of common beans. The research was arranged in a randomized block design with four replications. The following 6 spray nozzles were used: flat fan nozzles XR 110015 VS $\left(150 \mathrm{~L} \mathrm{ha}^{-1}\right)$ and XR $11002 \mathrm{VS}\left(200 \mathrm{~L} \mathrm{ha}^{-1}\right)$; cone nozzles TX VK $6\left(150 \mathrm{~L} \mathrm{ha}^{-1}\right)$ and TX VK $8\left(200 \mathrm{~L} \mathrm{ha}^{-1}\right)$; and twin flat fan nozzles TJ60 11002 VS $\left(150 \mathrm{~L} \mathrm{ha}^{-1}\right)$ and TJ60 $11002 \mathrm{VS}\left(200 \mathrm{~L} \mathrm{ha}^{-1}\right)$. The results showed that the loss of the spray solution on the soil occurred mainly within the bean rows and with a high intensity when using a nozzle spraying $200 \mathrm{~L} \mathrm{ha}^{-1}$. At 30 days after sowing, the TX $\left(150 \mathrm{~L} \mathrm{ha}^{-1}\right)$ nozzle was the only nozzle that promoted deposits of less than $210.0 \mu \mathrm{L} \mathrm{g}^{-1}$ of dry mass. The spray nozzles showed a good performance in the deposition of the spray solution on the weeds that occurred both within and between the rows. However, for both species there was great variation in individual deposits depending on their location in relationship to the plants.
\end{abstract}

Key words: Application technology, Bidens pilosa, Brachiaria plantaginea, nozzle, Phaseolus vulgaris.

\section{Introduction}

Common bean is one of the most cultivated crops in Brazil, with three harvests per year that occur in different seasons. Regardless of its importance, the average yield in many regions is still low due to crop

Received June 1, 2010. Accepted August 22, 2011. Corresponding author: neumarciovc@hotmail.com management factors, including the interference of weeds (Maciel et al., 2001); weed interference can decrease the yield of common bean crops up to $67 \%$ (Salgado et al., 2007). Thus, the use of herbicides for the control of weeds in this crop can greatly improve its yield. However, there are few reports in the literature to support information about the spray technology of these chemicals (Cobucci and Machado, 1999; Tomazela et al., 2006). 
In common bean production, herbicide application techniques in different plant growth stages result in drift losses, ranging between 49 and $88 \%$ of the total applied product (Chaim et al., 2000). In relation to the management of weeds, the product losses during the application, due to the inadequate technology of the application, may result in the failure of the weed control, the selection of resistant individuals to the herbicides and cause direct and indirect environmental contamination. In the specific case of herbicides applied in post-emergence stages, the best target deposition depends of factors, such as the application volume, nozzle type, angle of the nozzle, leaf morpho-anatomic structures, and architecture of the plant (Holloway, 1970; Taylor and Shaw, 1993; Berni et al., 1999).

Significant interactions between the sprayed volume and the kind of herbicide used may occur (Knoche, 1994). However, the efficiency of the herbicide treatment depends on the quantity of the activeproduct deposited onto the plant and also on the uniformity and distribution of the product all over the target's surface with drops of adequate size.

The presence of weeds near crop rows can promote irregularities in the deposition of the drops, thus, an increase in the herbicide rate is always necessary. However, high levels of efficiency of weed control may be achieved under field conditions by improving the spray technology.

This study aimed to evaluate the efficacy of different nozzles and spray volumes on the spray deposition over Bidens pilosa L. and Brachiaria plantaginea (Link) Hitch. plants present within rows and between rows of a common bean crop (Phaseolus vulgaris L.).

\section{Material and methods}

One trial was carried out at the experimental farm of the Faculdade de Ciências Agronômicas (FCA) of the Universidade Estadual Paulista (UNESP), campus of Botucatu, Sao Paulo, Brazil; located at $22^{\circ} 7^{\prime} 56^{\prime \prime} \mathrm{S}, 74^{\circ} 66^{\prime} 84^{\prime \prime}$ WGr, with an altitude of $762 \mathrm{~m}$. The deposition of a brilliant blue dye sprayed on "Carioca" common bean plants and the increased occurrence of the weeds, B. pilos $a$ and B. plantaginea, in areas of the bean plants were evaluated. The crop of common bean was sown on $02 / 09 / 2005$, using 16 seeds $\mathrm{m}^{-1}$, with spacing of $0.5 \mathrm{~m}$ between the rows. Fertilizer was applied at a rate of $160 \mathrm{~kg} \mathrm{ha}^{-1}$ using $\mathrm{N}-\mathrm{P}_{2} \mathrm{O}_{5}-\mathrm{K}_{2} \mathrm{O}$ fertilizer formula $04-14-08$, according to a previous analysis of the soil. The crop was irrigated during the experimental period using a sprinkler system, every three days, with water blade of $20 \mathrm{~mm}$.

The thinning of bean seedlings was performed at 7 days after sowing (DAS), leaving 11 plants $\mathrm{m}^{-1}$. The plants of B. pilosa arose naturally during the experiment (i.e., without being planted), whereas, on the same day that the bean seeds were sown, $2.0 \mathrm{~kg}$ of $B$. plantaginea seeds were distributed in the entire area of the trial to guarantee the presence of this species in the area. The weed species in the area of each plot were manually removed weekly to avoid interference.

The trial was performed in a randomized block design with four repetitions, where each plot was composed of 6 crop rows of 5 meters long, totaling an area of $15 \mathrm{~m}^{2}$. The Brilliant Blue food dye, FD\&C-1, at concentration of $500 \mathrm{ppm}$, was used as a tracer to determine the spray deposition on the common bean and weed plants. The spraying of dye solution was performed at 30 DAS, when the common bean plants were at the V4 stage (three trifoliate leaves), whereas the weeds were at stages of 2-3 pairs of leaves for B. pilos $a$ and 3-4 tillers for $B$. plantaginea and average population densities of 51 and 112 plants $\mathrm{m}^{-2}$, respectively.

The treatments were applied using a $\mathrm{CO}_{2}$ pressurized sprayer, with four spray nozzles spaced at $0.5 \mathrm{~m}$ between them. The calibration conditions are presented in Table 1. The plots were protected by plastic divider boards $(1.5 \times 2.5 \mathrm{~m})$ 
during the spray application to avoid any drift to the neighboring plots. The environmental conditions during the applications ranged from 28.9 to $33.9^{\circ} \mathrm{C}$ in the temperature and 53 to $65 \%$ in the relative humidity, and the average wind speed was $2.5 \mathrm{~km} \mathrm{~h}^{-1}$.

Table 1. Spray calibration conditions used to obtain each spray volume studied.

\begin{tabular}{lccc}
\hline Nozzles & $\begin{array}{c}\text { Spray volume } \\
\left(\mathrm{L} \mathrm{ha}^{-1}\right)\end{array}$ & $\begin{array}{c}\text { Pressure } \\
(\mathrm{kPa})\end{array}$ & $\begin{array}{c}\text { Speed } \\
\left(\mathrm{km} \mathrm{h}^{-1}\right)\end{array}$ \\
\hline XR 110015 VS & 150 & 175 & 3.6 \\
XR 11002 VS & 200 & 175 & 3.6 \\
TX VS 6 & 150 & 500 & 3.6 \\
TX VS 8 & 200 & 500 & 3.6 \\
TJ60 11002 VS & 150 & 175 & 4.8 \\
TJ60 11002 VS & 200 & 175 & 3.6 \\
\hline
\end{tabular}

Plastic boxes with (dimensions of $11.5 \times 11.5$ x $3.0 \mathrm{~cm}$ ) were used as artificial targets and placed in each experimental plot with the objective of assessing the amount of tracer deposited on the soil. The boxes were distributed before the application of the treatments along the four central rows of the plot, placing four plastic boxes in each row and four between the rows. Immediately after application of the dye spray, random samples were collected in each plot, harvesting 25 common bean plants and 25 plants of B. pilosa and $B$. plantaginea present in and between the crop rows. Subsequently, the dye tracer depositions were quantified with a double-axis visible UV spectrophotometer (GBC, model Cintra 20) for measuring the absorbance at a wavelength of $630 \mathrm{~nm}$, according to the methodology described by Souza et al. (2007). The plant dry mass was determined by collecting the plants placing them in paper bags and drying in an air oven for 72 $\mathrm{H}$ at $65^{\circ} \mathrm{C}$.

The statistical analysis of the deposits on the common bean plants and weeds were conducted separately by comparing the performance of the studied nozzles, by species, to avoid interference of the different stages of development (Souza et al., 2007). For B. pilosa and B. plantaginea we used a factorial double $6 \times 2$ (6 nozzles $\times 2$ positions - weeds located in rows and between the rows) design. We used a factorial double $6 \mathrm{x}$ 2 (6 nozzles $x 2$ positions - collectors positioned in the rows and between the rows) for the spray deposition on the soil. The results of the deposits, expressed in $\mu \mathrm{L} \mathrm{g}^{-1}$ of dry mass, as proposed by Maciel et al. (2001), were submitted to an analysis of variance by the F test, and the means were compared by the LSD test $(\mathrm{P} \leq 0.05)$ using the statistical program, SISVAR 5.0.

\section{Results and discussion}

The mean values of the spray that reached the soil both within and between the rows of the common bean crop after the treatment application are presented in Table 2. It is noteworthy that depending on the purpose of spraying may consider these results as a loss by drift. There was no statistical difference in the interaction between the nozzles and the position of the artificial targets. However, considering the mean of all of the nozzles and spray volumes, it was observed that the drift between the rows was $90.4 \%$ higher than those obtained within the rows at 30 DAS. Similarly, Berni et al. (1999) did not find differences in the drift of the deposits on the soil within or between the rows of a crop of common beans at 63 DAS using flat fan nozzles (models $110^{\circ}$-SF-01 and $110^{\circ}$-SF-02) or cone nozzles (D2-23 and D3-25) with spray volumes of $200 \mathrm{~L} \mathrm{ha}^{-1}$.

The XR, TX and TJ60 nozzles with spray volumes of $200 \mathrm{~L} \mathrm{ha}^{-1}$ resulted in average losses of 66.5 , 69.4 and $68.1 \%$, respectively, when compared to the total volume sprayed; for volumes of $150 \mathrm{~L} \mathrm{ha}^{-1}$, the average soil deposition provided by the XR, TX and TJ60 nozzles were 67.9, 67.3 and 65.4\%, respectively, when compared to the total volume sprayed. It was observed that the XR nozzle at a spray volume of $200 \mathrm{~L} \mathrm{ha}^{-1}$ promoted drifts of 28.2, 26.7 and $22.5 \%$ higher than the XR, TX and TJ60 nozzles, respectively, at a spray volume of $150 \mathrm{~L} \mathrm{ha}^{-1}$. According to Bauer and Raetano (2003) and Raetano and Bauer (2004), the use 
Table 2. Mean values of the spray deposition on the soil within and between the rows of a common bean crop at 30 DAS.

\begin{tabular}{lcccc}
\hline & & Row & Between row & Means \\
\cline { 3 - 5 } Nozzles & Spray volume $\left(\mathrm{L} \mathrm{ha}^{-1}\right)$ & & $\left(\mathrm{L} \mathrm{ha}^{-1}\right)$ & \\
\hline XR 110015 VS & 150 & 30.76 & 65.39 & $48.07 \mathrm{c}$ \\
XR 11002 VS & 200 & 54.86 & 79.00 & $66.93 \mathrm{a}$ \\
TX VS 6 & 150 & 33.05 & 65.07 & $49.06 \mathrm{c}$ \\
TX VS 8 & 200 & 38.29 & 84.12 & $61.21 \mathrm{abc}$ \\
TJ60 11002 VS & 150 & 36.78 & 66.90 & $51.84 \mathrm{bc}$ \\
TJ60 11002 VS & 200 & 41.08 & 86.69 & $63.88 \mathrm{ab}$ \\
Means & & $39.14 \mathrm{~B}$ & $74.53 \mathrm{~A}$ & \\
\hline $\mathrm{F}_{\text {Nozzle }}$ (N) & $2.796^{*}$ & & & \\
$\mathrm{~F}_{\text {Position }}($ Po) & $78.923^{* *}$ & & & \\
$\mathrm{~F}_{\text {(N) x (Po) }}$ & $0.797 \mathrm{~ns}$ & & & \\
$\mathrm{~F}_{\text {Block }}$ & $2.178 \mathrm{~ns}$ & & \\
LSD (row) & 8.105 & & \\
LSD (column) & 14.039 & & \\
CV (\%) & 24.280 & & \\
\hline
\end{tabular}

Means followed by a different capital letter in a row and the are different lower case letters in a column (LSD test, $\mathrm{P} \leq 0.05$ ).

$*$ Significant $(\mathrm{P} \leq 0.05)$.

$* *$ Significant $(\mathrm{P} \leq 0.01)$. ns: not significant.

of fans to inject air in spray bar to 26 days after emergence (DAE) of bean plants can provide up to $60 \%$ loss of volume applied to plants.

Thus, in the applications of herbicides to control weeds at the post-emergence stage, a residual effect of the product could also be the elimination of the seed bank in the area. Alternatively, the residual effect on the soil of some post-emergence herbicides could either control the weeds or reduce the seed bank in the areas of the common bean crop.

We found that the nozzles provided spray depositions that were similar to each other. Only the XR nozzle $\left(200 \mathrm{~L} \mathrm{ha}^{-1}\right)$ showed a superior performance, with a spray deposition $39.4 \%$ higher than the lowest that was observed (Table 3).

According to Maciel et al. (2001), spray applications performed with the XR and TX nozzles without surfactant resulted in increases of 106.4 and $66.9 \%$, respectively, on the spray deposition over common bean plants when compared with the same nozzles spraying mixes with the surfactant, Aterbane BR, at $0.5 \% \mathrm{v} \mathrm{v}^{-1}$. The authors propose that this may have occurred due to of the lack of adherence of the drops on the leaves owing to the reduction of the surface tension of the liquid by the inclusion of the surfactant.

At 30 DAE, Cunha et al. (2005) found 21.5 and $61.1 \%$ more drop deposition in the upper and lower parts of bean plants, respectively, using a spray volume of $250 \mathrm{~L} \mathrm{ha}^{-1}$ instead of $125 \mathrm{~L} \mathrm{ha}^{-1}$. The authors also observed that the droplets formed in the applications using the hollow cone nozzle (ATR - Alumina Turbulence) were more likely to drift than those produced with the flat fan nozzle (API - Alumina Plastic ISO), especially when using low spray volumes. Similarly, Raetano and Bauer (2004) found that there was no effect of air assistance along the spray bar on the levels of the deposits on bean plants at 26 DAE; in general, the treatments with higher volumes of applica- 
Table 3. Mean values of the spray deposition on common bean plants at 30 DAS.

\begin{tabular}{lcc}
\hline Nozzles & $\begin{array}{c}\text { Spray volume } \\
\left(\mathrm{L} \mathrm{ha}^{-1}\right)\end{array}$ & $\begin{array}{c}\text { Deposits } \\
\left(\mu \mathrm{L} \mathrm{g}^{-1} \text { dry mass }\right)\end{array}$ \\
\hline XR 110015 VS & 150 & $230.64 \mathrm{ab}$ \\
XR 11002 VS & 200 & $286.83 \mathrm{a}$ \\
TX VS 6 & 150 & $205.76 \mathrm{~b}$ \\
TX VS 8 & 200 & $243.55 \mathrm{ab}$ \\
TJ60 11002 VS & 150 & $224.32 \mathrm{ab}$ \\
TJ60 11002 VS & 200 & $243.93 \mathrm{ab}$ \\
\hline $\mathrm{F}_{\text {Nozzle }}$ & $1.670^{*}$ & \\
$\mathrm{~F}_{\text {Block }}$ & $0.707^{\text {ns }}$ & \\
LSD & 63.656 & \\
CV (\%) & 17.660 & \\
\hline
\end{tabular}

Means followed by a different letter are different (LSD test, $\mathrm{P} \leq 0.05$ ).

$*$ Significant $(\mathrm{P} \leq 0.05)$.

ns: not significant.

tion (100 $\left.\mathrm{L} \mathrm{ha}^{-1}\right)$ had significantly higher average deposits on the plant, when compared with the lower application volumes $\left(60 \mathrm{~L} \mathrm{ha}^{-1}\right)$.

Table 4 shows the means values of spray deposition over the $B$. pilosa plants located within and between the rows at 30 DAS. It is evident that for the weeds located within the crop rows, only the TX nozzle (150 $\left.\mathrm{L} \mathrm{ha}^{-1}\right)$ provided the lowest deposition (less than $70.00 \mu \mathrm{L} \mathrm{g}^{-1}$ ). However, the opposite occurred for the deposits on the leaves of $B$. pilosa located between the rows, where we found the highest values of deposits with the use of the TX nozzle ( $\left.150 \mathrm{~L} \mathrm{ha}^{-1}\right)$, followed by the XR nozzle (200 L ha-1).

Comparing the spray deposition on the B. pilosa plants located within and between the rows, we verified that there was no statistical difference in the deposits provided by the XR $\left(150 \mathrm{~L} \mathrm{ha}^{-1}\right)$ and TJ60 (150 L ha $\left.{ }^{-1}\right)$ nozzles. However, there were approximately 56.4 and $622.1 \%$ higher deposition on the weeds located between the rows than within the rows with the use of the XR $\left(200 \mathrm{~L} \mathrm{ha}^{-1}\right)$ and TX (150 L ha $\left.{ }^{-1}\right)$ nozzles, respectively. Opposite results were obtained for the nozzles TX $(200 \mathrm{~L}$ $\left.\mathrm{ha}^{-1}\right)$ and TJ60 (200 $\left.\mathrm{L} \mathrm{ha}^{-1}\right)$ which provided 74.9 and $64.4 \%$ higher deposition in on the weeds
Table 4. Mean values of the spray deposition on B. pilosa plants located within and between the rows of a common bean crop at 30 DAS.

\begin{tabular}{lcrc}
\hline & \multirow{2}{*}{$\begin{array}{c}\text { Spray volume } \\
\left(\mathrm{L} \mathrm{ha}^{-1}\right)\end{array}$} & \multicolumn{2}{c}{$\left(\mu \mathrm{L} \mathrm{g}^{-1}\right.$ dry mass $)$} \\
\hline XR 110015 VS & 150 & $272.73 \mathrm{aA}$ & $231.11 \mathrm{cdA}$ \\
XR 11002 VS & 200 & $262.25 \mathrm{aB}$ & $410.29 \mathrm{abA}$ \\
TX VS 6 & 150 & $69.28 \mathrm{bB}$ & $500.25 \mathrm{aA}$ \\
TX VS 8 & 200 & $378.88 \mathrm{aA}$ & $216.52 \mathrm{~dB}$ \\
TJ60 11002 VS & 150 & $251.53 \mathrm{aA}$ & $360.25 \mathrm{bcA}$ \\
TJ60 11002 VS & 200 & $364.48 \mathrm{aA}$ & $221.76 \mathrm{~dB}$ \\
\hline $\mathrm{F}_{\text {Nozzle }}(\mathrm{N})$ & $0.731 \mathrm{~ns}$ & & \\
$\mathrm{~F}_{\text {Position }}($ Po) & $4.668 *$ & & \\
$\mathrm{~F}_{(\mathrm{N}) \text { x (Po) }}$ & $11.971 * *$ & & \\
$\mathrm{~F}_{\text {Block }}$ & $1.499 \mathrm{~ns}$ & & \\
LSD & 131.102 & & \\
CV (\%) & 30.90 & & \\
\hline
\end{tabular}

Means followed by a different capital letter in a row and the are different lower case letters in a column (LSD test, $\mathrm{P} \leq 0.05$ ).

*Significant $(\mathrm{P} \leq 0.05)$.

**Significant $(\mathrm{P} \leq 0.01)$

ns: not significant.

located the rows than within the between the rows, respectively.

Souza et al. (2007) mentioned that interference may occur in the deposition of spray droplets due to the stage of development of the plant, as the germination of weeds is irregular: on any given day, one can observe weeds in various stages and of various sizes. In addition, the small size of many weeds and their position in the field, whether or not they are near the crop, may also increase the variability of individual deposits. These authors also show that, in the standardization of weeds in the same range of dry mass or leaf area in different positions in the field (in-row and between rows), there are more deposits on the plants between the rows than on those located within the rows.

Similar to the observations for B. pilosa, the TX nozzle (150 $\mathrm{L} \mathrm{ha}^{-1}$ ) also provided the lowest spray deposition over the $B$. plantaginea plants located within the crop rows. The TJ60 nozzle (200 L $\mathrm{ha}^{-1}$ ) produced the highest average deposition on 
the $B$. plantaginea plants located between the rows (Table 5).

Tomazela et al. (2006) verified that the use of the XR nozzle with angles of $-15^{\circ},-30^{\circ}, 15^{\circ}$ and $30^{\circ}$ in the spray bar provided increases of the spray deposition over B. plantaginea plants of 55.3, 40.7, 53.4 and $70.6 \%$, respectively, as compared to the angle of $90^{\circ}$ that is often used in agricultural sprays.

In this study, considering the performance of each nozzle on the spray deposition over the $B$. plantaginea plants, it was found that only the XR nozzle (150 $\mathrm{L} \mathrm{ha}^{-1}$ ) showed no differences in the coverage of plants located within rows and between the rows of common bean at 30 DAS.

Comparing the spray deposition on the $B$. plantaginea plants located within and between the rows, we verified that there was no statistical difference in the deposits provided by the XR $\left(150 \mathrm{~L} \mathrm{ha}^{-1}\right)$ nozzle. However, there were approximately 463.6 and $85.3 \%$ higher deposition on the weeds located between the rows than within the rows with the use of the TX $\left(150 \mathrm{~L} \mathrm{ha}^{-1}\right)$ and
TJ60 (200 L ha $\left.{ }^{-1}\right)$ nozzles, respectively. Opposite results were obtained for the nozzles XR $(200 \mathrm{~L}$ $\left.\mathrm{ha}^{-1}\right)$, TX (200 L ha-1) and TJ60 (150 L ha $\left.{ }^{-1}\right)$ which provided $75.8,115.4$ and $191.6 \%$ higher deposition in on the weeds located the rows than within the between the rows, respectively.

Souza et al. (2007) found that the flat fan nozzle (110-SF-01), working at $250 \mathrm{~L} \mathrm{ha}^{-1}$, provided a spray deposition that was $34 \%$ higher for $B$. plantaginea plants at the 2-8 leaf stage and located between rows, when compared to the plants located in the rows of a soybean crop (V2-4 stage). It is important to emphasize that the diversity in leaf morphological that exists between B. pilosa and B. plantaginea, including the trichomes, stomata, cuticles and waxes, can have a great influence on the drop deposition and its adherence to the leaves and, consequently, on the absorption of the herbicide (Ferreia et al., 2002; Procópio et al., 2003; Monquero et al., 2001; Costa et al., 2005a; Costa et al., 2005b). However, there are few available reports on morphological studies related to leaf anatomy and correlated with drop deposition over weeds.

Table 5. Mean values of the spray deposition on B. plantaginea plants located within and between the rows of a common bean crop at 30 DAS.

\begin{tabular}{lccc}
\hline & $\begin{array}{c}\text { Spray volume } \\
\left(\mathrm{L} \mathrm{ha}^{-1}\right)\end{array}$ & Row & \multicolumn{1}{c}{ Between row } \\
\cline { 3 - 4 } Nozzles & 150 & $331.78 \mathrm{aA}$ & $306.49 \mathrm{bA}$ \\
\hline XR 110015 VS & 200 & $483.69 \mathrm{aA}$ & $275.12 \mathrm{bB}$ \\
XR 11002 VS & 150 & $44.23 \mathrm{bB}$ & $249.27 \mathrm{bA}$ \\
TX VS 6 & 200 & $397.51 \mathrm{aA}$ & $184.56 \mathrm{bB}$ \\
TX VS 8 & 150 & $465.49 \mathrm{aA}$ & $159.62 \mathrm{bB}$ \\
TJ60 11002 VS & 200 & $306.95 \mathrm{aB}$ & $568.70 \mathrm{aA}$ \\
TJ60 11002 VS & $4.800^{* *}$ & & \\
\hline $\mathrm{F}_{\text {Nozzle }}(\mathrm{N})$ & $1.698 \mathrm{~ns}$ & \\
$\mathrm{~F}_{\text {Position }}($ Po) & $6.980^{* *}$ & & \\
$\mathrm{~F}_{(\mathrm{N}) \text { x (Po) }}$ & & \\
$\mathrm{F}_{\text {Block }}$ & $1.854 \mathrm{~ns}$ & & \\
LSD & 182.233 & & \\
CV (\%) & 40.28 & & \\
\hline
\end{tabular}

Means followed by a different capital letter in a row and the are different lower case letters in a column (LSD test, $\mathrm{P} \leq 0.05$ ).

** Significant $(\mathrm{P} \leq 0.01)$.

ns: not significant. 
Hess and Falk (1990) have proposed that the use of surfactants might be useful to solve the problem of herbicide deposition and absorption on those leaves where waxes or trichomes represent a negative influence.

Maciel et al. (2001) reported that the drop deposition on Brachiaria decumbens plants located under common bean plants of mixtures containing Aterbane $\left(0,5 \% \mathrm{~V} \mathrm{~V}^{-1}\right)$ and sprayed by TX nozzles can provide 289.2 and $172.9 \%$ more coverage than the XR nozzle with or without the same surfactant, respectively. Thus, the umbrella effect provided by common bean plants during the herbicide spraying can be minimized when the surface tension is reduced and when the nozzles produce drops with smaller diameters. Alternatively, this proceeding may increase the occurrence of drift, as it is necessary that spraying activities be executed at the ambient conditions that are most favorable (Lima and Machado-Neto, 2001; Penckowski et al., 2003).

Some studies showed that the effectiveness of herbicides was low when the spray volumes were below $50 \mathrm{~L} \mathrm{ha}^{-1}$, as compared to volumes greater than $180 \mathrm{~L} \mathrm{ha}^{-1}$; thus, the optimum spraying volume should be determined empirically for each type of herbicide (Mcmullan, 1995).
Tomazela et al. (2006) evaluated the deposition of drops using a XR nozzle for B. plantaginea plants at the stage of 2 to 3 leaves and observed that, as the spraying volume per hectare decreased, there were increases in the percentage of deposits on the plants and, concomitantly, decreases in the percentage deposited on the soil, indicating greater efficiency in reach the biological target.

In general, we conclude that, regardless of the nozzle used, the drift of spray solutions to the soil occurred mainly between the rows of the common bean crop and that this drift was intensified with the use of nozzles that offered a greater volume of application. The different nozzles evaluated did not influence the deposition of the drops on the bean plants at 30 DAS, except for the TX nozzle (150 $\left.\mathrm{L} \mathrm{ha}^{-1}\right)$, with the lowest average deposits.

In terms of the spray deposition on the B. pilosa and $B$. plantaginea weeds, we found that the spray nozzles evaluated provided large variations in individual deposits on the plants located both within and between the rows, possibly due to a lack of standardization of the stages of development of both species and the proximity of the weeds to the common bean crop.

\section{Resumen}

A.C.P. Rodrigues-Costa, D. Martins, N.V. Costa y M.R.R. Pereira. 2011. Depósitos de las gotas de pulverización sobre las malezas en frijol. Cien. Inv. Agr. 38(3): 357-365. Los fracasos en el control de malezas en frijol (Phaseolus vulgaris L.) pueden estar relacionados con inadecuadas técnicas de aplicación de herbicidas. Se determinó la cantidad de deposición de las gotas de pulverización en las plantas de Bidens pilosa L. y Brachiaria plantaginea (Link) Hitch., presentes en la línea y entre la línea de frijol. Se evaluaron 6 boquillas de pulverización: de abanico plano XR 110.015 (150 L ha ${ }^{-1}$ ) y XR 11002 VS (200 L ha-1), de cono TX VK 6 (150 $\mathrm{L} \mathrm{ha}^{-1}$ ) y TX VK 8 (200 $\left.\mathrm{L} \mathrm{ha}^{-1}\right)$ y de doble abanico plano TJ60 11002 VS (150 L ha-1) y TJ60 11002 VS (200 L ha $\left.{ }^{-1}\right)$. Se utilizó un diseño de bloques al azar con 4 repeticiones. Los resultados mostraron que la pérdida de caldo al suelo se produjo principalmente en las líneas de frijol y con mayor intensidad con el uso de volumen de aplicación de $200 \mathrm{~L} \mathrm{ha}^{-1}$. A los 30 días post siembra del frijol, la boquilla TX (150 $\left.\mathrm{L} \mathrm{ha}^{-1}\right)$ fue el único tratamiento que promovió depósitos 
menores a $210,0 \mu \mathrm{L} \mathrm{g}^{-1}$ de materia seca. Las boquillas de pulverización evaluadas mostraron un buen desempeño en la deposición de gotas en la maleza B. pilosa y B. plantaginea presentes en la línea y en la entre línea. Sin embargo, existió una gran variación en los depósitos individuales de ambas especies según su ubicación en relación al cultivo.

Palabras clave: Tecnología de aplicación, Bidens pilosa, boquilla de pulverización, Brachiaria plantaginea, Phaseolus vulgaris.

\section{References}

Bauer, F. C., and C. G. Raetano. 2003. air-assisted boom sprayer and spray deposition on bean plants. Scientia Agrícola. 60: 211-215.

Berni, R.F., V.O.F. Machado, G.R. Costa, G. Barata, and R. S. Paula. 1999. Avaliação da cobertura de gotas provocada por diferentes bicos de pulverização na cultura do milho e do feijão. Pesquisa Agropecuária Tropical. 29: 49-52.

Chaim, A., P.J. Valarini, and L.C. Pio. 2000. Avaliação de perdas na pulverização de agrotóxicos na cultura do feijão. Pesticidas: Revista de Ecotoxicologia e Meio Ambiente 10: 65-74.

Cobucci, T., and E. Machado. 1999. Seletividade, eficiência de controle de plantas daninhas e persistência no solo de imazamox aplicado na cultura do feijoeiro. Planta Daninha 17:419-432.

Costa, N.V., D. Martins, R.A. Rodella, and L.D.N.C. Costa. 2005a. Droplet deposition during spray and leaf ph in aquatic weed control. Scientia Agricola 62 : 227-234.

Costa, N.V., D. Martins, R.A. Rodella, and L.D.N.C. Costa. 2005b. Ph foliar e deposição de gotas de pulverização em plantas daninhas aquáticas: Brachiaria mutica, Brachiaria subquadripara e Panicum repens. Planta Daninha 23: 295-304.

Cunha, J.P.A.R., M.M. Teixeira, R.F. Vieira, and H.C. Fenandes. 2005. Deposição e deriva de calda fungicida aplicada em feijoeiro, em função de bico de pulverização e de volume de calda. Revista Brasileira de Engenharia Agrícola e Ambiental 9: 133-38.

Ferreira, E.A., S.O. Procópio, E.A.M. Silva, A.A. Silva, and R.J.N. Rufino. 2002. Estudos anatômicos de folhas de espécies de plantas daninhas. II - Bidens pilosa, Emilia sonchifolia, Ageratum conyzoides e Sonchus asper. Planta Daninha 20: 327-335.

Hess, F.D., and R.H. Falk. 1990. Herbicide deposition on leaf surfaces. Weed Science 38: 280-288.
Holloway, P.J. 1970. Surface factors affecting the wetting of leaves. Pesticide Science 1: 56-63.

Knoche, M. 1994. Effect of droplet size and carrier volume on performance of foliage applied herbicides. Crop Protection 13: 163-178.

Lima, P.R.F., and J.G. Machado-Neto. 2001. Otimização da aplicação de fluazifop-p-butil em pósemergência na cultura de soja (Glycine max). Planta Daninha 19: 85-95.

Maciel, C.D.G., R.T. Souza, R.H. Silva, E.D. Velini, and L.B. Lemos. 2001. Avaliação do depósito e distribuição da calda de pulverização em plantas de feijoeiro e Braquiaria decumbens. Planta Daninha 19: 103-110.

Mcmullan, P.M. 1995. Effect of spray volume, spray pressure and adjuvant volume on efficacy of sethoxydim and fenoxaprop-p-ethyl. Crop Protection 14: 549-554.

Monquero, P.A., P.J. Christoffoleti, J.A. Matas, and A. Heredia. 2004. Caracterização da superfície foliar e das ceras epicuticulares em Commelina benghalensis, Ipomoea grandifolia e Amaranthus hybridus. Planta Daninha 22: 203-210.

Penckowski, L.H., M.J. Podolan, and R.F. LópezOvejero. 2003. Influência das condições climáticas no momento da aplicação de herbicidas pósemergentes sobre a eficácia de controle de nabiça (Raphanus raphanistrum) na cultura de trigo. Planta Daninha 21: 435-442.

Procópio, S.O., E.A. Ferreira, E.A.M. Silva, A.A. Silva, R.J.N. Rufino, and J.B. Santos. 2003. Estudos anatômicos de folhas de plantas daninhas de grande ocorrência no Brasil. III. Galinsoga parviflora, Crotalaria incana, Conyza bonariensis e Ipomoea cairica. Planta daninha 21: 1-9.

Raetano, C.G., and F. Bauer. 2004. Deposição e perdas da calda em feijoeiro em aplicação com assistência de ar na barra pulverizadora. Bragantia 63: 309-315.

Salgado, T.P., M.S. Salles, J.V.F. Martins, and P.L.C. Alves. 2007. Interferência das plantas daninhas 
no feijoeiro carioca. Planta Daninha 25: 443-448.

Souza, R.T., E.D. Velini, and L.A. Palladini. 2007.

Aspectos metodológicos para análise de depósi-

tos de pulverizações pela determinação dos depósitos pontuais. Planta Daninha 25: 195-202.

Taylor, W.A., and G.B. Shaw. 1993. The effect of drop speed, size and surfactant on the deposition of spray on barley and radish or mustard. Pesticide Science 14: 659-665.

Tomazela, M.S., D. Martins, S.R. Marchi, and E. Negrisoli. 2006. Avaliação da deposição da calda de pulverização em função da densidade populacional de Brachiaria plantaginea, do volume e do ângulo de aplicação. Planta Daninha 24: 183-189. 
